\title{
The Influence of Consumer's Practical Value on Overseas Direct Purchase Intention
}

\author{
Mi-ra Park , Dept. of Smart Convergence Consulting, Hansung University, Seoul, 02876, Korea \\ *Yen-yoo You, Dept. of Smart Convergence Consulting, Hansung University, Seoul, 02876, Korea, \\ threey0818@hansung.ac.kr \\ ${ }^{*}$ Corresponding Author
}

\begin{abstract}
Background/Objectives: Every year, more and more consumers use overseas direct purchases. Therefore, we investigated how consumers with practical value orientation have an influence on purchase intention.

Methods/Statistical analysis: In this study, research hypotheses and models were established based on previous studies, and independent variables were set as practical values, as parameters were site attributes and logistics attributes, and dependent variables were set as purchase intentions. Data was collected through questionnaires, and a confirmatory factor analysis was conducted to secure validity and reliability. Data were analyzed using AMOS 22.0.

Findings: The results of this study confirmed that the practical value propensity of consumers has a significant effect on the site convenience, site safety, and site design variables of overseas direct purcha se site attributes, and has a significant effect on the delivery speed and delivery accuracy of the logistics attribute. However, it was confirmed that only the convenience of the site and the accuracy of delivery affect the purchase intention. This confirmed that the convenience of the site for consumers with practical value-oriented overseas direct purchase, and securing the accuracy of delivery affects the purchase intention.

Improvements/Applications: It will be an important resource in establishing online marketing strategies for SMEs in Korea, paying attention to the relationship that affects the intention to purchase overseas direct purchase.
\end{abstract}

Keywords: Overseas direct purchase, Practical value, Site properties, Logistics properties, Purchase intention

$\begin{array}{lll}\text { Received: 09.12.2020 } & \text { Accepted: 11.01.2021 } & \text { Published: 06.02.2021 }\end{array}$

\section{INTRODUCTION}

As the Internet becomes more widespread in daily life, consumers can shop in various forms. Since it is not limited by physical distance, online shopping has led to direct overseas purchase and has grown rapidly as it has become popular. According to the data from the Korea Customs Service, the amount of overseas direct purchases in 2017 was $\$ 2.11$ billion, an increase of $35.6 \%$ from the previous year, recording the largest ever. The growth of direct overseas purchases is changing shopping trends and consumers' purchasing patterns.

With the diversification of purchasing patterns, consumers have become important not only about the economic benefits of purchasing the target product, but also the overall practical satisfaction of the functional benefits of the site in purchasing behavior. Therefore, the purpose of this study is to empirically verify how the practical value propensity of consumers who use overseas direct purchase affects purchase intention according to the attributes of the site and logistics.

In recent years, as online overseas direct purchases have attracted great attention from consumers in Korea, consumers who mainly use overseas direct purchases are called "overseas direct purchases" [1].

First, infrastructure development is the background for the increase in overseas direct purchase. The emergence of international e-commerce platforms and the development of international delivery systems and online payment systems have improved the convenience of overseas direct purchases. Second, it is the lowered psychological barrier of entry for consumers to overseas direct purchases. The increased familiarity with the language of consumers and the use of translation services provided on sites such as Google increased their desire for direct overseas purchases. Third is the institutional support of information. As tariffs such as FTAs between major trading partners have been cut, and the tax-free limit is being adjusted, consumers are more comfortable with overseas direct purchases. 
The purchase behavior of consumers who value practical shopping value is logical, rational, and task-related, which reflects the cognitive aspect as an overall evaluation of the economical purchase or functional benefits of a product [2].

Among the attributes that an online shopping mall must have, it emphasizes the convenience of use of the site such as product and service sales promotion, convenience, user interface, and payment method [3]. The importance of quality was confirmed through SERVQUAL and SERVPERF, which suggested that the quality of logistics service reinforces relationship orientation with customers who use internet shopping malls, and that consumer satisfaction is a parameter between relationship orientation and customer loyalty [4].

Logistics management helps companies enhance customer service and reduce expenses [5].

Purchasing intention refers to the consumer's planned future behavior, and it is said that it is the probability that beliefs and attitudes will be transferred to the actual purchase behavior. It can be an important determinant [6].

Based on previous studies, this study will empirically show the relationship between the practical value of consumers, the attributes of the site, and the attributes of logistics among the factors that influence the purchase intention of overseas direct purchase.

\section{Materials and Methods}

\subsection{Collecting data}

In this study, a questionnaire was distributed to general days that used overseas direct purchases using individual visit surveys, e-mail, and internet, and a 5-point Likert scale was used. analysis.

A total of 270 questionnaires were collected, but 182 valid samples were used for empirical

\subsection{Research model}

Based on previous studies, this study was to confirm the effect of consumer's practical value propensity on site properties and logistics properties, and also to determine how site properties and logistics properties affect purchase intentions. Figure 1.

Therefore, this study is schematically constructed by constructing a research model as shown in

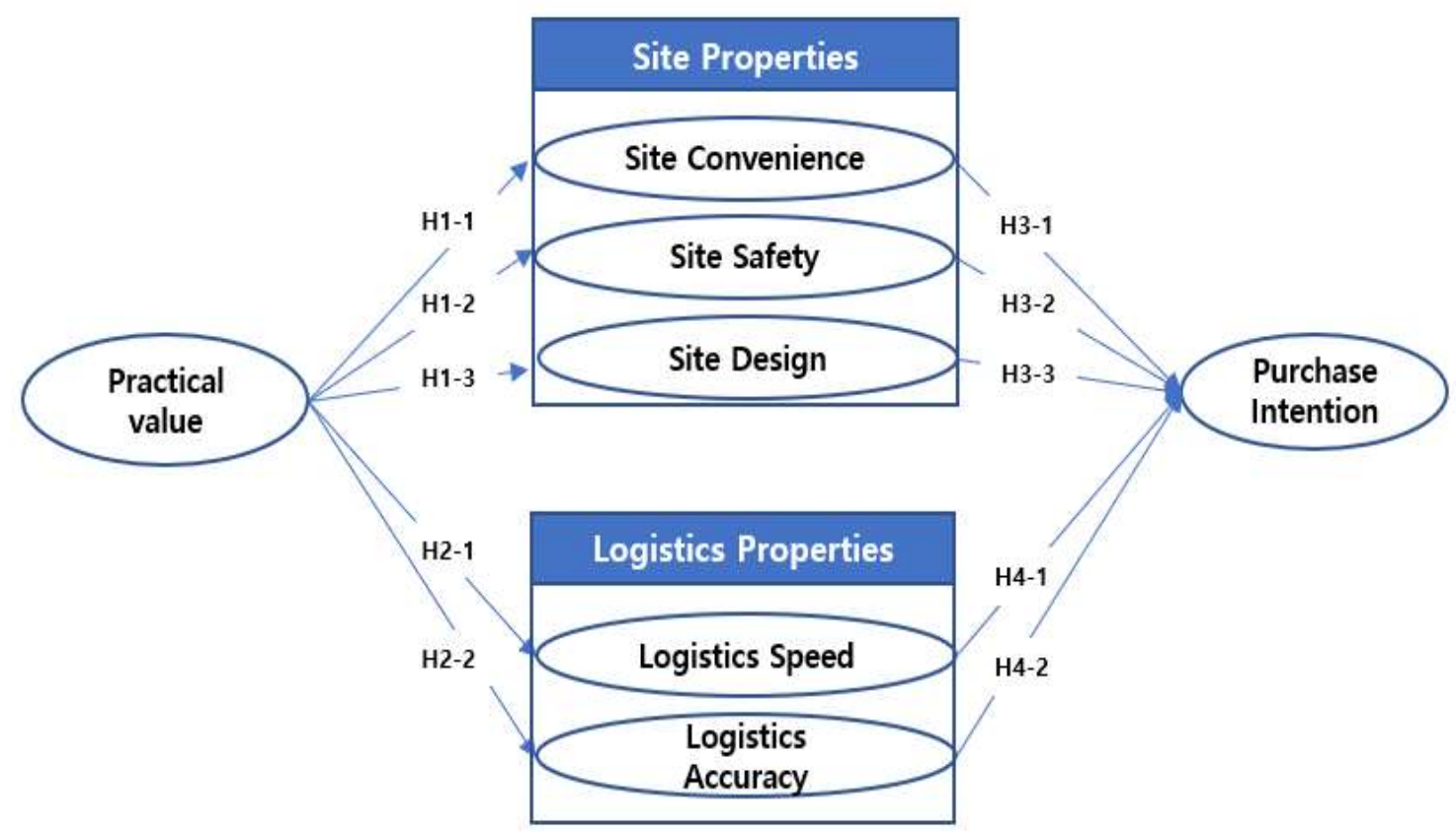

Figure 1 Research model 


\subsection{Research Hypothesis}

Based on Based on previous studies, hypotheses were established for the practical value propensity of consumers, site attributes (site convenience, site safety, site design), logistics attributes (logistics speed, logistics accuracy), and purchase intention.

H1-1: Practical value will have a positive (+) effect on site convenience.

H1-2: Practical value will have a positive $(+)$ effect on site safety.

H1-3: Practical value will have a positive $(+)$ effect on site design.

H2-1: Practical value will have a positive (+) effect on logistics speed.

H2-2: Practical value will have a positive (+) effect on logistics accuracy.

H3-1: Site convenience will have a positive $(+)$ effect on purchase intention.

H3-2: Site safety will have a positive $(+)$ effect on purchase intention.

H3-3: Site design will have a positive $(+)$ effect on purchase intention.

H4-1: Logistics speed will have a positive (+) effect on purchase intention.

H4-2: Logistics accuracy will have a positive (+) effect on purchase intention.

\subsection{Operational Definition of Variables}

Independent variables of this study are practical value, parameters are site convenience, site safety, site design, logistics speed, logistics accuracy, and dependent variables are purchase intention.

All measured variables adopted in this study were based on previous studies to ensure validity, and the definition of the measured variables and the composition of the questionnaire were organized in Table1.

Table 1 Questionnaire

\begin{tabular}{|c|c|c|c|c|}
\hline \multicolumn{2}{|c|}{ Evaluation items } & Operational definition & source & questions \\
\hline \multicolumn{2}{|c|}{ Practical value } & $\begin{array}{l}\text { Efficient purchase of overseas direct } \\
\text { purchase } \\
\text { Economics of direct overseas direct } \\
\text { - Needs for overseas direct } \\
\text { Practicality of direct overseas }\end{array}$ & $\begin{array}{l}\text { Eroglu, S., \& Harrell, G. D. } \\
\text { (1986) [6] } \\
\text { Kwang-hyun, } \\
\text { lee(2016)[7] } \\
\text { Babin, Barry J., William R. } \\
\text { Darden, and Mitch } \\
\text { Griffin(1994)[15] }\end{array}$ & 4 \\
\hline \multirow{3}{*}{$\begin{array}{l}\text { Site } \\
\text { properties }\end{array}$} & $\begin{array}{l}\text { Site } \\
\text { convenience }\end{array}$ & $\begin{array}{l}\text { Quickness after accessing the site } \\
\text { Convenience of information search site } \\
\text { structure } \\
\text { Quick explanation of problems in use } \\
\text { - Provide government abundance } \\
\text { Quick update of new information } \\
\text { Ease of searching and comparing multiple } \\
\text { products and services }\end{array}$ & $\begin{array}{l}\text { Spiller\&Lohse(1998)[3] } \\
\text { i-hyun,Kang(2003)[8] }\end{array}$ & 6 \\
\hline & $\begin{array}{l}\text { Site } \\
\text { Safety }\end{array}$ & $\begin{array}{l}\text { Privacy Policy } \\
\text { - Possibility of leakage of personal information } \\
\text { - Risk of payment problems } \\
\text { - Computer system stability of overseas direct } \\
\text { purchase shopping malls }\end{array}$ & $\begin{array}{l}\text { Page,C.\&white,E.L(2002)[9] } \\
\text { Jaecheon Cho(2017)[10] }\end{array}$ & 4 \\
\hline & $\begin{array}{l}\text { Site } \\
\text { design }\end{array}$ & $\begin{array}{l}\text { - Screen harmony of the site } \\
\text { - Matching with the type of service } \\
\text { - Unique design } \\
\text { - Outstanding web design }\end{array}$ & $\begin{array}{l}\text { Spiller\&Lohse(1998)[3] } \\
\text { Mithas, et al.(2005)[11] }\end{array}$ & 4 \\
\hline
\end{tabular}




\begin{tabular}{|c|c|c|c|c|}
\hline \multirow{2}{*}{$\begin{array}{l}\text { Logistics } \\
\text { properties }\end{array}$} & $\begin{array}{l}\text { Logistics } \\
\text { Speed }\end{array}$ & $\begin{array}{l}\text { Fast delivery time } \\
\text { Quickness of goods in and out } \\
\text { Expedited handling of shipping related } \\
\text { changes }\end{array}$ & $\begin{array}{l}\text { Mentzer(2001)[12] } \\
\text { Jarvenpaa } \\
\text { Todd(1997)[4] and }\end{array}$ & $d^{3}$ \\
\hline & $\begin{array}{l}\text { Logistics } \\
\text { accuracy }\end{array}$ & $\begin{array}{l}\text { Delivery accuracy } \\
\text { - Aclivery method accuracy } \\
\text { Accuracy of the place to be delivered } \\
\text { - Delivery accuracy during peak season }\end{array}$ & $\begin{array}{l}\text { Saura et al.(2008)[13] } \\
\text { Mentzer(2001)[12] }\end{array}$ & 5 \\
\hline \multicolumn{2}{|c|}{ Purchase intention } & $\begin{array}{l}\text { Induce overseas direct purchase } \\
\text { Intention to purchase overseas direct } \\
\text { purchase } \\
\text { Impulsive purchase of overseas direct } \\
\text { purchase products } \\
\text { Possibility of positive word of mouth }\end{array}$ & $\begin{array}{l}\text { Eroglu, S., \& Harrell, G. D. } \\
(1986)[6] \\
\text { Davis(1989)[14], } \\
\text { Jarvenpaa } \\
\text { Todd(1997)[4] }\end{array}$ & d 4 \\
\hline
\end{tabular}

\section{Results and Discussion}

\subsection{Statistical analysis results}

\subsubsection{Confirmatory factor analysis}

Confirmatory factor analysis using AMOS 22.0 was conducted to secure the centralized validity of each variable in this study and to perform path analysis.

The analysis results confirmed that convergence validity was secured when all standardized loading values were 0.5 or more, and AVE values were all 0.5 or more, as in tabel2. The CR value of each constituent concept is more than 0.7 , which can be said to have convergence validity or internal consistency.

Table 2 Confirmatory factor analysis

\begin{tabular}{|c|c|c|c|c|c|c|c|}
\hline $\begin{array}{l}\text { Latent } \\
\text { variable }\end{array}$ & $\begin{array}{l}\text { Measured } \\
\text { variable }\end{array}$ & coefficient & $\begin{array}{l}\text { Standardization } \\
\text { coefficient }\end{array}$ & S.E & SMC & AVE & $\mathrm{CR}$ \\
\hline \multirow{2}{*}{ Practical Value } & PV1 & 1.000 & .635 & & .403 & \multirow{2}{*}{.725} & \multirow{2}{*}{.837} \\
\hline & PV2 & 1.516 & .865 & .234 & .784 & & \\
\hline \multirow{4}{*}{$\begin{array}{l}\text { Site } \\
\text { Convenience }\end{array}$} & SC2 & 1.000 & .846 & & .715 & \multirow{4}{*}{.581} & \multirow{4}{*}{.846} \\
\hline & SC3 & .932 & .795 & .080 & .632 & & \\
\hline & SC4 & .989 & .673 & .104 & .453 & & \\
\hline & SC5 & 899 & .716 & 088. & .513 & & \\
\hline \multirow{4}{*}{$\begin{array}{l}\text { Site } \\
\text { Safety }\end{array}$} & SS1 & 1.000 & .853 & & .727 & \multirow{4}{*}{.717} & \multirow{4}{*}{.910} \\
\hline & SS2 & 1.055 & .851 & .075 & .724 & & \\
\hline & SS3 & .973 & .826 & .072 & .682 & & \\
\hline & SS4 & 1.041 & .826 & .078 & .682 & & \\
\hline \multirow{4}{*}{$\begin{array}{l}\text { Site } \\
\text { Design }\end{array}$} & SD1 & 1.000 & .851 & & .725 & \multirow{4}{*}{.657} & \multirow{4}{*}{.883} \\
\hline & SD2 & .942 & .871 & .070 & .759 & & \\
\hline & SD3 & .854 & .698 & .084 & .487 & & \\
\hline & SD4 & .779 & .652 & .084 & .426 & & \\
\hline
\end{tabular}




\begin{tabular}{|c|c|c|c|c|c|c|c|}
\hline \multirow{3}{*}{$\begin{array}{l}\text { Logistics } \\
\text { Speed }\end{array}$} & LS1 & 1.000 & .861 & & .741 & \multirow{3}{*}{.711} & \multirow{3}{*}{.880} \\
\hline & LS2 & 1.031 & .904 & .071 & .818 & & \\
\hline & LS3 & .760 & .762 & .064 & .581 & & \\
\hline \multirow{5}{*}{$\begin{array}{l}\text { Logistics } \\
\text { Accuracy }\end{array}$} & LA1 & 1.000 & .798 & & .636 & \multirow{5}{*}{.627} & \multirow{5}{*}{89} \\
\hline & LA2 & 1.029 & .868 & .081 & .753 & & \\
\hline & LA3 & .829 & .744 & .079 & .553 & & \\
\hline & LA4 & 1.067 & .717 & .106 & .514 & & \\
\hline & LA6 & 1.094 & .701 & .112 & .491 & & \\
\hline \multirow{5}{*}{$\begin{array}{l}\text { Purchase } \\
\text { Intention }\end{array}$} & PI1 & 1.000 & .716 & & .513 & \multirow{5}{*}{728} & \multirow{5}{*}{.93} \\
\hline & PI2 & 1.137 & .837 & .105 & .701 & & \\
\hline & PI3 & 1.147 & .898 & .099 & .807 & & \\
\hline & PI4 & 1.087 & .841 & .100 & .707 & & \\
\hline & PI5 & 1.116 & .871 & .099 & .759 & & \\
\hline
\end{tabular}

model fit $\quad \chi^{2}=569.524(\mathrm{df}=302), \mathrm{CMIN} / \mathrm{df}=1.886, \mathrm{GFI}=.811, \mathrm{TLI}=.903, \mathrm{CFI}=.916$, RMSEA $=.071$

Next, the discriminant validity was evaluated by comparing the correlation coefficient between the square root of AVE and the concepts. Thus, the square root value of AVE was higher than the correlation coefficient, ensuring discriminant validity.

The analysis results are shown in Table 3.

Table 3 Discriminant validity analysis

\begin{tabular}{|c|c|c|c|c|c|c|c|}
\hline & (A) & (B) & $(\mathrm{C})$ & (D) & (E) & $(\mathrm{F})$ & (G) \\
\hline (A) Practical Value & 0.725 & & & & & & \\
\hline $\begin{array}{ll}\text { B) } & \text { Site } \\
\text { Convenience } & \\
\end{array}$ & 0.447 & 0.581 & & & & & \\
\hline (C) Site Safety & 0.319 & 0.516 & 0.717 & & & & \\
\hline (D) Site Design & 0.269 & 0.651 & 0.702 & 0.657 & & & \\
\hline (E) Logistics Speed & 0.107 & 0.434 & 0.447 & 0.399 & 0.711 & & \\
\hline $\begin{array}{l}\text { (F) Logistics } \\
\text { Accuracy }\end{array}$ & 0.298 & 0.485 & 0.546 & 0.463 & 0.625 & 0.627 & \\
\hline $\begin{array}{l}\text { (G)Purchase } \\
\text { Intention }\end{array}$ & 0.663 & 0.527 & 0.413 & 0.365 & 0.165 & 0.443 & 0.728 \\
\hline
\end{tabular}

\subsection{Hypothesis verification}

\subsubsection{Structural Equation Modeling}

The hypothesis of this study was verified using the structural equation model of AMOS 22.0 as shown in Figure 2.

In the structural equation model, the basis for the fit of each model is TLI (Tucker Lewis Index), CFI (Comparative Fit Index) values are .90 .95, and RMSEA (Root Mean Square Error of Approximation) values are .071. It was analyzed as a model with good fit. 


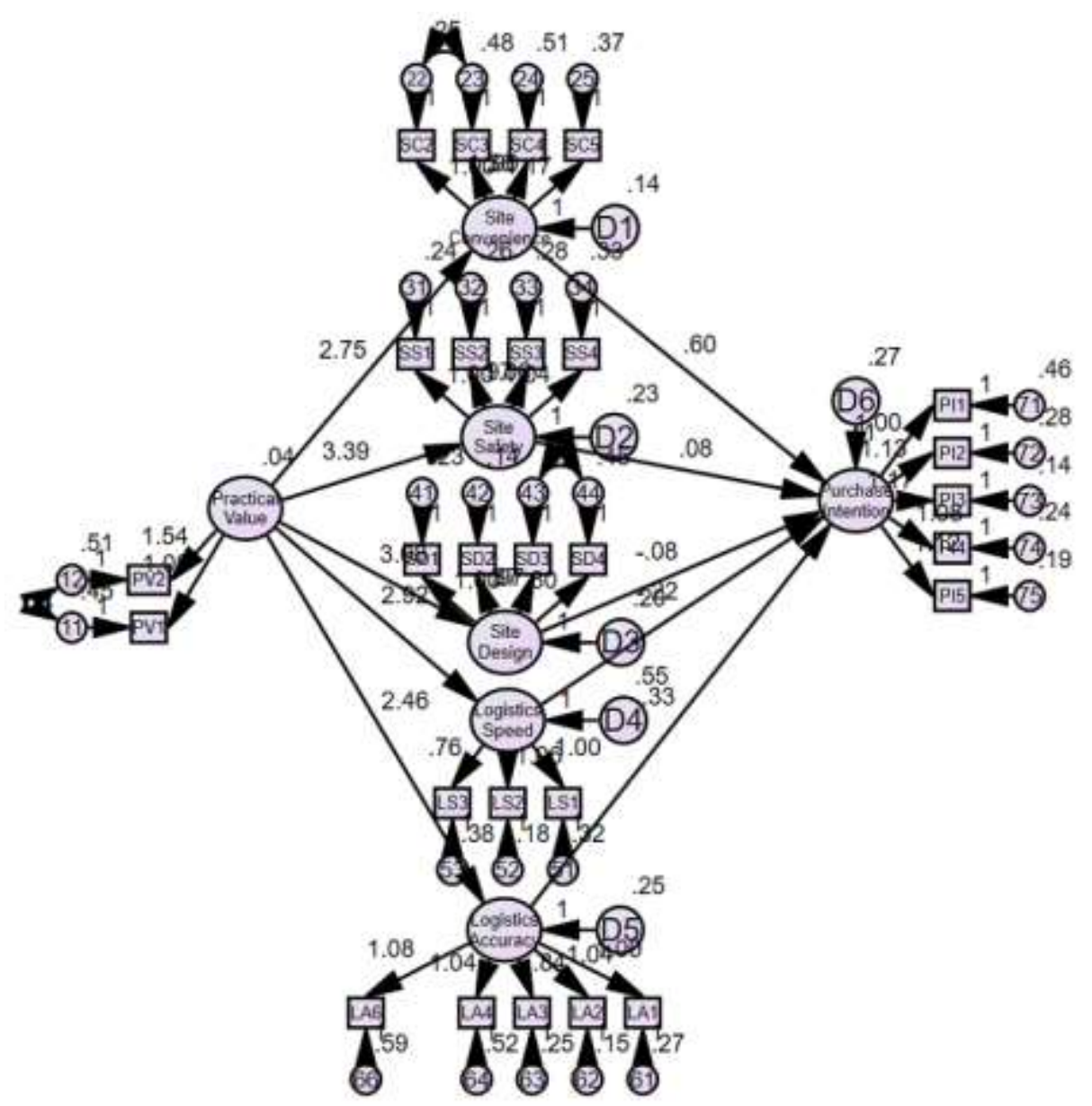

Figure 2 Structural Equation Modeling

The hypothesis Table 4 shows the results of analyzing the research model according to the structural equation model analysis.

The hypothesis that the practical value orientation will have a positive effect on the properties (site convenience, site safety, site design) and logistics properties (delivery promptness), and delivery accuracy) was adopted, but the purchase intention Only the hypothesis of delivery accuracy was adopted.

Table 4 Research model analysis

\begin{tabular}{l|l|l|l|l|l|l}
\hline Hypothesis & Model & B & $\beta$ & C.R & P & result \\
\hline H1-1 & Practical Value $\rightarrow$ Site Convenience & 2.750 & .814 & 3.186 & .001 & adoption \\
\hline H1-2 & Practical Value $\rightarrow$ Site Safety & 3.391 & .799 & 3.268 & .001 & adoption \\
\hline H1-3 & Practical Value $\rightarrow$ Site Design & 3.075 & .787 & 3.249 & .001 & adoption \\
\hline H2-1 & Practical Value $\rightarrow$ Logistics Speed & 2.922 & .595 & 3.113 & .002 & adoption \\
\hline H2-2 & Practical Value $\rightarrow$ Logistics Accuracy & 2.460 & .680 & 3.172 & .002 & adoption \\
\hline H3-1 & Site Convenience $\rightarrow$ Purchase Intention & .600 & .540 & 3.973 & $* * *$ & adoption \\
\hline H3-2 & Site Safety $\rightarrow$ Purchase Intention & .081 & .092 & .867 & .386 & Rejection \\
\hline H3-3 & Site Design $\rightarrow$ Purchase Intention & -.085 & -.088 & .823 & .410 & Rejection \\
\hline H4-1 & Logistics Speed $\rightarrow$ Purchase Intention & -.222 & -.291 & -3.388 & $* * *$ & Rejection \\
\hline H4-2 & Logistics Accuracy $\rightarrow \quad$ Purchase & .327 & .316 & 3.337 & $* * *$ & adoption \\
\hline
\end{tabular}




\begin{tabular}{c|c|c|c|c|c|}
\hline Model fit & $\chi^{2}=605.414(\mathrm{df}=311)$, CMIN $/ \mathrm{df}=1.947, \mathrm{GFI}=.805, \mathrm{TLI}=.896, \mathrm{CFI}=.908, \mathrm{RMSEA}=.073$ \\
\hline $\mathrm{p}<.05^{* *} \mathrm{p}<.01 \quad * * * \mathrm{p}<.001$
\end{tabular}

\section{Conclusion}

This study is meaningful in that it has verified the impact on purchase intention for consumers seeking the practical value of an increasing number of overseas direct online shopping malls.

The main results and implications of this study are as follows.

First, it was confirmed that consumers with a propensity to pursue practical values affect both the properties of the site and the logistics properties. This shows that consumers who want to obtain economic benefits also value both functional benefits of the site and practical satisfaction from product delivery.

Second, it was confirmed that only the site convenience of the site attribute and the delivery accuracy of the logistics attribute affect the purchase intention. This indicates that it is the accuracy rather than the speed of delivery that leads to the actual purchase intention. It is shown that consumers can purchase if they have sufficient understanding of the physical distance limit and the accuracy of delivery is ensured.

This study is expected to be meaningful in that it provided implications for the establishment of online marketing strategies for SMEs in Korea.

And, it is judged that various studies are needed by expanding additional variables in the future.

\section{Acknowledgment}

This research was financially supported by Hansung University.

\section{References}

[1] Seong-Ho Lee. (2014). The Impact of Consumer's Motivation on Attitude and Repurchase intention in Overseas direct purchase shopping. The e-Business studies, 15(6), 39-55. DOI: 10.15719/geba.15.6.201412.39

[2] Sherry. (1990). Rose Terry Cooke and the woman question : A study infiction and ideology. University of Minnesota. http://www.worldcat.org/oclc/26140855

[3] Spiller \& Lohse. (1998). Electronics Shopping. Communication od the ACM, 41(7), 81-85. https://doi.org/10.1145/278476.278491

[4] Jarvenpaa, S. L. \& Todd, P. A. (1997). Consumer Reactions to Electronic Shopping on the World Wide Web. International Journal of Electronic Commerce, 1(2), 58-88. https://doi.org/10.1080/10864415.1996.11518283

[5] Liu Chang, Jia YongFei, \& Kong Bei. (2019). Impact of Logistics Information Service on Customer Satisfaction: An Empirical Study with Assurance as the Moderator. International Journal of Advanced Science and Convergence, 1(1), 1-6. DOI: 10.22662/IJASC.2019.1.1.001.

[6] Eroglu, S., \& Harrell, G. D. (1986). Retailing Crowing : Theoretical and Strategic Implication. Journal of Retailing, 62(4), 346-363. https://psycnet.apa.org/record/1988-12513-001

[7] Kwang-hyun Lee. (2016). The Impact of Consumer's Emotion Response on Repurchase affected by Em otional, Practical and Usability Value In Open Market. Konkuk University.http://www.riss.kr/link?id= T13997039

[8] Jihyun Kang. (2003). Study on the Influence of Marketing Characteristics in the Internet Shopping Mall on Repurchasing of Internet Customers. Gyeonggi University. http://www.riss.kr/link?id=T9242951

[9] Page, C. \& White, E. L. (2002). Web Equity: a Framework for Building Consumer Value in Online Companies. Journal of Consumer Marketing, 19(3), 231-248. https://doi.org/10.1108/07363760210426058

[10] Jaecheon Cho. (2017). Study on the effects of online shopping mall sites attributeson repurchase inte ntion : focused on the moderating effect of site attachment. Gyeonggi University. http://www.riss.kr/l ink?id=T14461930

[11] Mithas,S.,Kriahnan,M.S \& Fornell,C. (2005). Effect of information technology investments on customer satisfaction : theory and evidence. Ross School of Business. University of Michigan. DOI: $10.2139 /$ ssrn. 901643 
[12] Mentzer, J. T., J. F. Daniel and G. M. Hult. (2001). Logistics Service quality as a segment-customized process. Journal of Marketing, 65(4), 82-104. DOI: 10.1509/jmkg.65.4.82.18390

[13] Saura, I. G., Francés, D. S., Contrí, G. B. and Blasco, M. F. (2008). Logistics service quality: A new way to loyalty. Industrial Management \& Data Systems, 108(5), 650-668. https://doi.org/10.1108/02635570810876778

[14] Davis,F.D. (1989). Perceived Usefulness, Perceived Ease of Use, and User Acceptance of Information Technology. MIS Quarterly. 13(3), 319-340. DOI: 10.2307/249008

[15] Babin, Barry J., William R. Darden, and Mitch Griffin. (1994). Work and/or Fun: Measuring Hedonic and Utilitarian Shopping Value. Journal of Consumer Research, 20(4), 644-656. https://www.jstor.org/stable/2489765 